\title{
Optimization and characterisation of commercial water-based volatile corrosion inhibitor
}

\author{
N. Cheng, ${ }^{1}$ B. Valdez-Salas, ${ }^{2} *$ P. Moe ${ }^{1}$ and J.S. Salvador-Carlos ${ }^{2}$ \\ ${ }^{I}$ Magna International Pte Ltd, 10 H Enterprise Road, 629834, Singapore \\ ${ }^{2}$ Materiales Avanzados y Corrosion, Instituto de Ingeniería de UABC, Mexicali Calle \\ Normal s/n, Parcela 44, 21100 Mexicali, Mexico \\ *E-mail: benval@uabc.edu.mx
}

\begin{abstract}
Volatile corrosion inhibitor (VCI) provides protection for metal surfaces. VCI coating and molecules attach themselves to metal surfaces to form both a physical film when contacted and an invisible thin film for indirect contact through Vapour (only a few molecules thick), thus inhibiting metals atmospheric corrosion. Optimization and characterisation of commercial water-based volatile corrosion inhibitor VCI (Vapour-Phase-Protection, VAPPRO 837C diluted commercial solution from CORPPRO) was prepared to determine their characteristics and effectiveness against corrosion of carbon steel. The main scope of this work is to characterise the rheological and corrosion inhibition properties of the VAPPRO 837C with varying formulations and processing parameters (coating and drying times). Different tests were performed to determine the corrosion behavior of inhibitor. The application of VCI on the metal surface was done by dip-coating process. An Electrochemical Workstation from $\mathrm{HCH}$ Instruments has been used to evaluate the corrosion inhibition efficiency of the VCI and to determine the corrosion rate of the uncoated and coated samples. In addition, viscosity tests were carried out in order to determine the rheological properties of the formulation, as well as Freeze-Thaw resistance of water-borne coatings and $\mathrm{pH}$ tests were done. A FTIR spectrometer has been used to determine the functional groups present at a specific concentration. Results reveal that the most effective VCI film was obtained from a 0.25 CORPPRO (Concentrated VCI) (vol\%) formulation using a coating time of $10 \mathrm{~min}$ and a drying time of $24 \mathrm{~h}$. Therefore, 0.25 CORPPRO would be the optimum concentration to be used because it is able to achieve the highest corrosion inhibition efficiency with the optimum coating drying time.
\end{abstract}

Key words: corrosion inhibitor, vapour phase protection, dip-coating.

Received: March 19, 2019. Published: April 30, 2019

doi: $\underline{10.17675 / 2305-6894-2019-8-2-16}$

\section{Introduction}

Metallic corrosion is a world-wide problem caused by the interacition of the metal surface with the surrounding environment. It has always been problematic to metal constructs and tools as degradation or rusting of metals due to the tendency to return to their natural state 
(oxides or other corrosion leading to a weakening of mechanical properties and failure) [1]. Replacing them outright is expensive and, with resources on Earth becoming more limited, problematic in the long run [2]. Thus, corrosion protection of metallic infraestructures is preferable by their cost over part replacement and prolongs the working life of the product in the field, with many methods to do so currently available such as corrosion inhibitors, coatings and cathodic protection [3].

Volatile corrosion inhibitors are widely used as corrosion control and prevention method. They are a part of a class of corrosion inhibiting compounds with a finite vapour pressure where the inhibitors are transported to the target metal through space to condense on the metal surface forming a protective film, lowering the corrosion rate of the metal itself [4]. Factors that determine the efficiency of VCIs are the concentration of VCI compounds, the period of exposure and vapour pressure [5]. The main advantages of these inhibitors are their user-friendly and application VCI onto the metal. Other benefits include to reach crevices, blind holes and other "difficult to reach" areas. Limitations include being temporary films as they can be removed easily, are used at fairly low concentrations and a higher concentration is needed for the self-healing effect which could increase the cost of using it and corrosion protection may not be the only requirement, with others such as colour limitation and film hardness needed. It is due to these factors that they are largely ignored in industrial maintenance coatings [6]. However, a long side corrosion-resistant materials and corrosion protection coatings, corrosion inhibitors are still researched and developed to further lower corrosion rates and to reduce the costs of corrosion [7].

An example of these inhibitors is the ammonia. This compound has been used as a VCI to protect immersed and exposed parts of steam boiler circuits at the beginning of the 20 th century [8]. In the 1940s, less odorous, safer and more effective substances were used for protection. With more than 1000 types of VCI compounds known today, only a few are used as these are acceptably efficient, cost effective and environmentally friendly [9]. One type of inhibitor used in VCIs is salts of dicyclohexylamine such as dicyclohexyl ammonium nitrite (DCHN) and cyclohexylamine carbonate (CHC) [10]. The VCI developed by Magna International uses amine carboxylate as the inhibitor. It is a salt synthesized by neutralizing carboxylic acid with a blend of amines, with the number of carbon atoms ranging from 1 to 26 , with corrosion inhibition increasing with the number of carbon. Other than corrosion inhibition, it is also used for boundary lubrication, emulsification and detergency [11].

Recently, there has been a shift in using water-based VCIs, which are less hazardous to human health and are environmentally friendly, as opposed to oil-based VCIs. By substituting the organic solvent with water as the transport medium, it would lower the levels of volatile organic compounds (VOCs) emitted by VCIs [12]. This study aims to deduce the concentration of the VCI developed by Magna International, Vappro 837C, that can offer the best corrosion protection and under what conditions can this be achieved. The 
effects of the concentration of inhibitors, coating time, drying time and temperature on its performance are studied and observed.

\section{Experimental}

\section{Preparation of metal samples}

Carbon steel UNS G10100 disks with $0.7853 \mathrm{~cm}^{2}$ surface area were prepared and de-rusted by hand using 600 grit abrasive.paper. Lastly, the samples were raised with deionised water and isopropyl alcohol to remove debris from the de-rusting procedure [13].

\section{Determination of corrosion rate and corrosion inhibitor efficiency}

Electrochemical corrosion tests were performed using a $\mathrm{HCH}$ Instruments Electrochemical Workstation and a three electrode cell array. The electrochemical method was DC Polarization using the coated and uncoted samples as working electrode, and a silver/silver chloride $(\mathrm{Ag} / \mathrm{AgCl})$ as reference electrode, while a platinum mesh was used as counter electrode. A schematic diagram of the electrochemical corrosion cell is given in Figure 1.

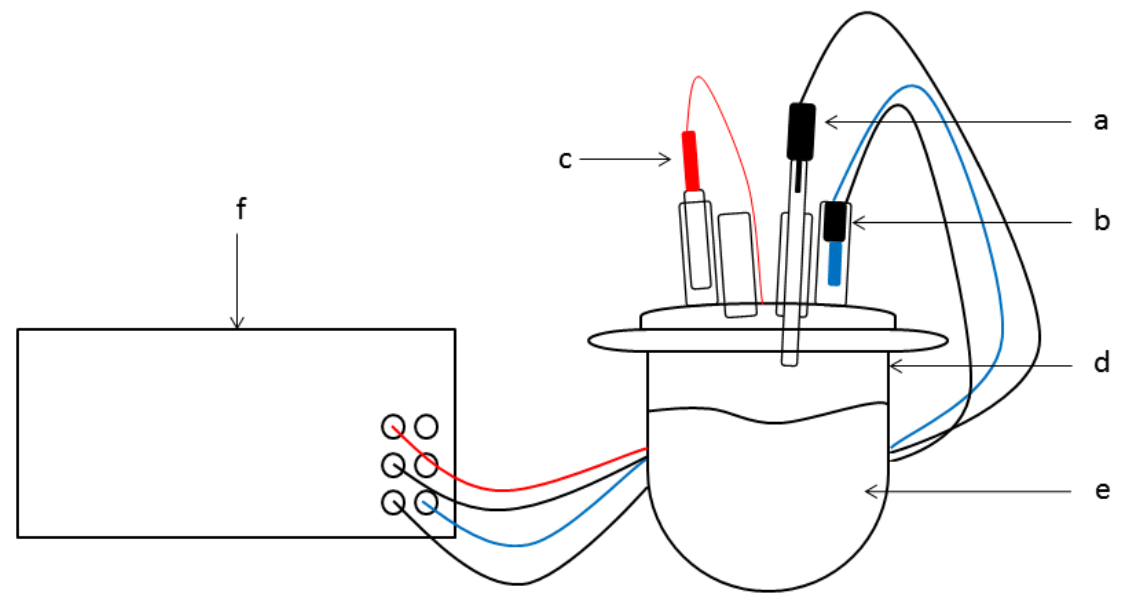

Figure 1. Schematic diagram of three-electrodes cell: (a) reference electrode $(\mathrm{Ag} / \mathrm{AgCl})$,

(b) working electrode (sample), (c) counter-electrode (platinum Pt), (d) electrolyte container,

(e) electrolyte, (f) potentiostat.

The parameters established for the electrochemical test were $10 \mathrm{mV} \mathrm{s}^{-1}$ scan rate and the polarization range from -100 to $-600 \mathrm{mV}$ vs corrosion potential. Final results were adjusted by Tafel analysis to calculate corrosion rates and the percentage of corrosion inhibition efficiency. The corrosive media was Singapore tap water with the typical values of microbiological and physicochemical parameters shown in Table 1 [14].

The corrosion rate was calculated using the following formula: 


$$
\text { Corrosion rate }=k\left[\frac{\left(a \cdot i_{\text {corr }}\right)}{(n \cdot D)}\right]
$$

where $D$ is density of metal specimen, $a$ is atomic weight, $i_{\text {corr }}$ is corrosion current density, $n$ is the number of electrons lost and $k$ is the constant, which depends on unit of corrosion rate. For this work, the $k$ value applied was $0.00327 \mathrm{~mm} /(\mathrm{A} \mathrm{cm}$ year).

Table 1. Microbiological and physical chemical parameters typical values.

\begin{tabular}{|c|c|c|}
\hline Parameter & Unit & Typical value \\
\hline \multicolumn{3}{|l|}{ Microbiological } \\
\hline Escherichia coli (E. coli) & $\mathrm{cfu} / 100 \mathrm{~mL}$ & $<1$ \\
\hline \multicolumn{3}{|l|}{ Physical } \\
\hline Colour & Hazen & $<5$ \\
\hline Conductivity & $\mu \mathrm{S} / \mathrm{cm}$ & $<250$ \\
\hline Chlorine & $\mathrm{mg} / \mathrm{L}$ & $<2.0$ \\
\hline $\mathrm{pH}$ & Units & $7.0-8.5$ \\
\hline Total Dissolved solids (TDS) & $\mathrm{mg} / \mathrm{L}$ & $<150.0$ \\
\hline Turbidity & NTU & $<5$ \\
\hline \multicolumn{3}{|l|}{ Chemical } \\
\hline Ammonia (as $\mathrm{N}$ ) & $\mathrm{mg} / \mathrm{L}$ & $<1.0$ \\
\hline Calcium & $\mathrm{mg} / \mathrm{L}$ & $4.0-20.0$ \\
\hline Chloride & $\mathrm{mg} / \mathrm{L}$ & $<20.0$ \\
\hline Copper & $\mathrm{mg} / \mathrm{L}$ & $<0.05$ \\
\hline Fluoride & $\mathrm{mg} / \mathrm{L}$ & $<0.50$ \\
\hline Iron & $\mathrm{mg} / \mathrm{L}$ & $<0.04$ \\
\hline Manganese & $\mathrm{mg} / \mathrm{L}$ & $<0.05$ \\
\hline Nitrite (as N) & $\mathrm{mg} / \mathrm{L}$ & $<11.0$ \\
\hline Sodium & $\mathrm{mg} / \mathrm{L}$ & $<20.0$ \\
\hline Sulphate & $\mathrm{mg} / \mathrm{L}$ & $<5.0$ \\
\hline Silica (as $\mathrm{SiO}_{2}$ ) & $\mathrm{mg} / \mathrm{L}$ & $<3.0$ \\
\hline Total Organic Carbon (TOC) & $\mathrm{mg} / \mathrm{L}$ & $<0.50$ \\
\hline Total Hardness (as $\mathrm{CaCO}_{3}$ ) & $\mathrm{mg} / \mathrm{L}$ & $<50.0$ \\
\hline Zinc & $\mathrm{mg} / \mathrm{L}$ & $<0.10$ \\
\hline
\end{tabular}


Based on the corrosion rates of the metal sample before and after coating, the corrosion inhibition efficiency was calculated based on the formula below [15]:

$$
\text { Corrosion inhibition efficiency }(\%)=\frac{\left(C R_{\text {uninhibited }}-C R_{\text {inhibited }}\right)}{C R_{\text {uninhibited }} \times 100}
$$

where $C R_{\text {uninhibited }}$ is the corrosion rate of uninhibited sample and $C R_{\text {inhibited }}$ is the corrosion rate of inhibited sample.

Formulation of VAPPRO $837 C$

A concentrated corrosion inhibitor solution based on amine carboxylates was used to prepare formulations of commercial VAPPRO $837 \mathrm{C}$ at concentrations of $0.25,0.50,0.75$ and $1.0 \mathrm{ml} / 100 \mathrm{ml}(\mathrm{v} / \mathrm{v})$ solution. The concentrated corrosion inhibitor CORPPRO was diluted in deionized water to reach the concentrations mentioned above for testing. In order to ensure the stability of the mixtures, the solutions left stand for one day before being used for testing.

\section{Coating of metal samples}

VAPPRO 837C was applied on clean metal samples of carbon steel by immersion at three different times using a clock glass as a coating reservoir. Different immersion times were selected for the coating process (10 min, $20 \mathrm{~min}, 30 \mathrm{~min}, 8 \mathrm{~h}$ and $24 \mathrm{~h}$ ). After the coating, the samples were removed using tweezers and left to dry. Immediately after drying, the metal samples were tested using potentiostat to calculate their corrosion rates. Eventually the immersion coating and drying time were also varied in order to establish the best condition for an optimum protection efficiency.

\section{Elevated temperature drying}

Figure 2 shows the set-up used for the elevated drying temperature test. The light bulb was first switched on to heat up the interior of the box. When the temperature inside the box stops fluctuating, metal samples that have just completed coating were clipped onto the string for drying. After drying, the samples were immediately tested using the potentiostat to determine their corrosion rates. 


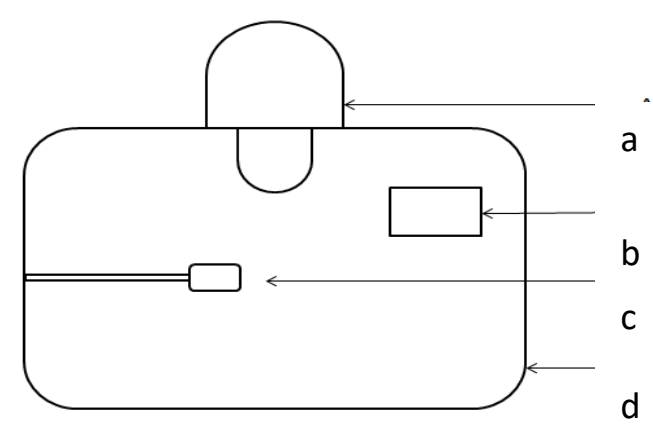

Figure 2. Elevated temperature drying set-up: (a) light bulb, (b) _ al thermometer, (c) sample and (d) container.

\section{Freeze-Thaw Test}

The freeze thaw test was conducted following the ASTM D2243-95(2008) standard [16]. The formulations were first tested for their initial viscosity (before freezing). After the first testing, the formulations were stored at $-18^{\circ} \mathrm{C}$ in a freezer for 17 hours. Subsequently, the formulations were removed and thawed at room temperature for 7 hours. Posterior to thawing, the formulations were placed back in the freezer at $-18^{\circ} \mathrm{C}$ and one more cycle of freeze-thaw was carried out. After the final thawing step was completed, the formulations were tested for their viscosity. The viscosity before and after freeze-thawing were compared to determine the freeze-thaw stability of the formulations.

\section{FTIR Analysis}

A Fourier Tranform Infrarred analysis was conducted on a 0.25 CORPPRO formulation using the Attenuated Total Reflectance (ATR) method. A background scan was first carried out. After which, 2-3 drops of the formulation was added onto the zinc selenide crystal surface using a disposable dropper. The formulation was then scanned, and the resulting spectrum was analysed.

\section{Results and Discussion}

\section{Polarisation Curves}

The Annex 1 shows the potentidynamic polarisation curves (Figures 4 to 7) and Annex 2 presents the data from these curves. The results were grouped according to the drying time and compared with their concentrations. The behavior of the polarization curves depends of the inhibitor such as cathodic, anodic and organic inhibitors [18]. For the organic inhibitors, the effect of the solution in the metal sample can be presented by a mixed behavior [19]. The results in this work suggest that the behavior of the polarization curves could change due to different factors such as the concentration, the coating time and the drying time. But it is possible to follow a tendency. 
For all curves, the catodic and anodic slopes showed the same behavior but the position of potential and current changed regarding the blank. With a drying time of $1 \mathrm{~h}$, results showed that for any concentration, the polarization curve had a nobler position when the coating time was below $30 \mathrm{~min}$. As well, the value of the current decrease when a coating time was below $30 \mathrm{~min}$. This behavior is repeated on $2 \mathrm{~h}$ of drying time, but this changed when a $5 \mathrm{~h}$ or $24 \mathrm{~h}$ of drying time was applied. In this case, the nobler positions were obtained when a coating time was over $30 \mathrm{~min}$.

As a result of this way of acting, samples with inhibitor presented an effect of corrosion inhibition. Also observed in the values of corrosion efficiency and corrosion rate because all samples with inhibitor had a better performance in the environment. This may be due to the formation of a protective film of molecules on the metal surface and a mixedeffect of inhibition. Different articles have suggested this mechanism of inhibition [20, 21]. Most VCIs form a film by surface adsorption upon hydrolysis or dissociation. The presence of amino groups, carboxylate anions and the $\pi$-bond between carbon atoms enhance the corrosion-inhibiting [22].

\section{Corrosion Reduction Efficiency}

The effect of drying time on corrosion reduction efficiency is shown in Tables 6 to 9 (Annex 2). The data gathered suggests that increasing the drying time, the corrosion reduction efficiency becomes stable for any time of immersion or inhibitor concentration. It can be seen with a drying time of $5 \mathrm{~h}$ and $24 \mathrm{~h}$ where is presented with a small variation of efficiency for 10, 20, and $30 \mathrm{~min}$ for any concentration. However the highest corrosion efficiency was provided with $1 \mathrm{~h}$ of drying time (91.29\%), but it is not uniform regard the concentration.

This could be because while the coating appears to be dry visually after 20 min of drying, there could still be some water content present in the film which promotes corrosion. It is also possible that the protective film of inhibitor molecules have not been properly organized for drying times before $5 \mathrm{~h}$. This suggests that the optimum drying time should be around $24 \mathrm{~h}$.

This optimum drying time of $24 \mathrm{~h}$ is also conducive for practical consideration of working hours in the industry. It would be easy to keep track of the end of the drying time and ensure that it ends within working hours so that the metals can be stored immediately after drying.

Similarly, the effect of concentration of CORPPRO can be interpreted. The highest corrosion reduction efficiency was provided with a CORPPRO concentration of 0.5 when the drying time was $1 \mathrm{~h}, 2 \mathrm{~h}$, and $5 \mathrm{~h}$. For $24 \mathrm{~h}$ the highest corrosion reduction efficiency was obtained with a concentration of $0.25(85.07 \%)$, nevertheless the concentration of 0.5 is close to this efficiency $(82.27 \%)$.

Through varying the coating time of CORPPRO, it was observed that the corrosion reduction efficiency of the formulations is different according to drying time. For 1 and $2 \mathrm{~h}$ 
of drying the efficiency does not show a stable trend varying coating time. On the other hand for $5 \mathrm{~h}$ and $24 \mathrm{~h}$ of drying the corrosion reduction efficiency is stable from $10 \mathrm{~min}$ to $8 \mathrm{~h}$ of coating time. This suggests that increasing the coating time beyond $30 \mathrm{~min}$ has no significant effect on the corrosion reduction efficiency compared to a coating time of $30 \mathrm{~min}$.

This could be because at 30 min the surface of the metal substrate is fully saturated with inhibitor molecules and the metal surface-inhibitor interactions have stabilised. Therefore any further coating time would not cause a decrease in corrosion, while a lower coating time would result in the substrate's surface not being saturated with inhibitor molecules which correlates to a higher corrosion rate.

Considering the cost of time for a corporation, using a coating time of 10 min would be optimum as this would allow a fast processing time without any loss in corrosion inhibition.

\section{Effect of drying at elevated temperatures}

Through varying the temperature of drying, it was observed that drying at an elevated temperature of about $30^{\circ} \mathrm{C}$ obtains higher corrosion reduction efficiency. This can be seen from the $30^{\circ} \mathrm{C}$ drying obtaining a corrosion reduction efficiency of $58.6 \%$ while the $20^{\circ} \mathrm{C}$ drying obtained a corrosion reduction efficiency of 38\%, as shown in Table 2 below.

Table 2. Effect of temperature during drying on corrosion reduction efficiency of 0.25 CORPPRO for 30 min coating time.

\section{Temperature $\left({ }^{\circ} \mathrm{C}\right)$}

\section{Corrosion Reduction Efficiency (\%)}

\subsection{CORPPRO 30 min coating 2 h room temperature drying}

This could be because at elevated temperatures, the inhibitor molecules have more kinetic energy and are more mobile and thus more likely to orient themselves such that the polar functional groups faces the metal surface to preferentially form a protective film over the surface of the metal substrate, therefore resulting in an increase in corrosion reduction efficiency for the metal sample that was dried at elevated temperatures [17].

After $2 \mathrm{~h}$ drying at elevated temperatures, the surface of the metal sample still appeared wet on visual inspection. This is likely because the box used to contain the samples at elevated temperatures also limited the ventilation to a small area. This would reduce the rate of evaporation of the wet coating layer. Therefore for future testing of drying at elevated temperatures, it would be suggested to carry out the drying in a wellventilated area. 
Compared to samples that were dried at room temperature and not contained in a box but left in a well-ventilated area and had a dry surface on visual inspection, the samples dried at elevated temperatures showed higher corrosion reduction efficiency. This suggests that the corrosion reduction efficiency is not directly related to the water content present in the coated film, but rather on the complete formation of the protective film of inhibitor molecules.

\section{Freeze-thaw tests}

By varying the concentration of anti-freeze (Ethylene glycol) in the formulations, it was observed that all the formulations froze at $-18^{\circ} \mathrm{C}$. It was also observed that the viscosities of all the formulations remained around $29 \mathrm{cP}$ after undergoing the freeze-thaw test, as shown in Table 3. For all the formulations, there was no significant change in the viscosity after two cycles of freeze-thawing. Further testing is required in order to determine if the viscosity of the formulations will remain consistent after going through more freeze-thaw cycles.

The 0.25 CORPPRO formulations froze even after the addition of $1 \%$ ethylene glycol anti-freeze agent. To prevent the freezing of the formulations at $-18^{\circ} \mathrm{C}$, a higher concentration of anti-freeze agent would have to be used.

Table 3. Effects of freeze-thawing on the viscosity of 0.25 CORPPRO formulations with and without $1 \%$ antifreeze.

\begin{tabular}{cccc}
\hline \multirow{2}{*}{ \% Antifreeze } & \multicolumn{3}{c}{ Viscosity (cP) } \\
\cline { 2 - 4 } & Before freeze & After freeze & Freeze \\
\hline $\begin{array}{c}\text { Freeze Thaw 1 with 1\% } \\
\text { antifreeze }\end{array}$ & 28.2 & 30.9 & Yes \\
$\begin{array}{c}\text { Freeze Thaw 2 with 1\% } \\
\text { antifreeze }\end{array}$ & 29.3 & 28.3 & Yes \\
Freeze Thaw 1 w/o antifreeze & 31.2 & 30.0 & Yes \\
Freeze Thaw 2 w/o antifreeze & 28.0 & 30.6 & Yes \\
\hline
\end{tabular}

pH test for varying concentrations of CORPPRO

Through varying the concentration of CORPPRO, it was observed that the $\mathrm{pH}$ is above 9 for all concentrations, as shown in Table 4. The MSDS of CORPPRO states that it has a $\mathrm{pH}$ of 9, therefore it can be seen that diluting CORPPRO with distilled water does not affect its $\mathrm{pH}$. For all formulations, the $\mathrm{pH}$ is below 11 and thus, they will not cause skin irritation. 
Table 4. Effect of concentration of CORPPRO on $\mathrm{pH}$ of formulations with different concentrations.

CORPPRO Concentration (vol\%)

0.25

0.50

0.75

1.0

\section{Average pH}

9.60

9.60

10.60

10.7

Since the $\mathrm{pH}$ of the formulations does not vary much as the concentration of CORPPRO varies, it would not be viable to use $\mathrm{pH}$ as a measure to determine the concentration of CORPPRO formulations during manufacturing. It would be advised to use viscosity instead of $\mathrm{pH}$ to determine the concentration of formulations produced during manufacturing.

Functional Group Determination by FTIR

Figure 3 below shows the FTIR spectrum of 0.25 CORPPRO. The significant peaks were identified and their correlated functional groups peaks are shown in Table 5.

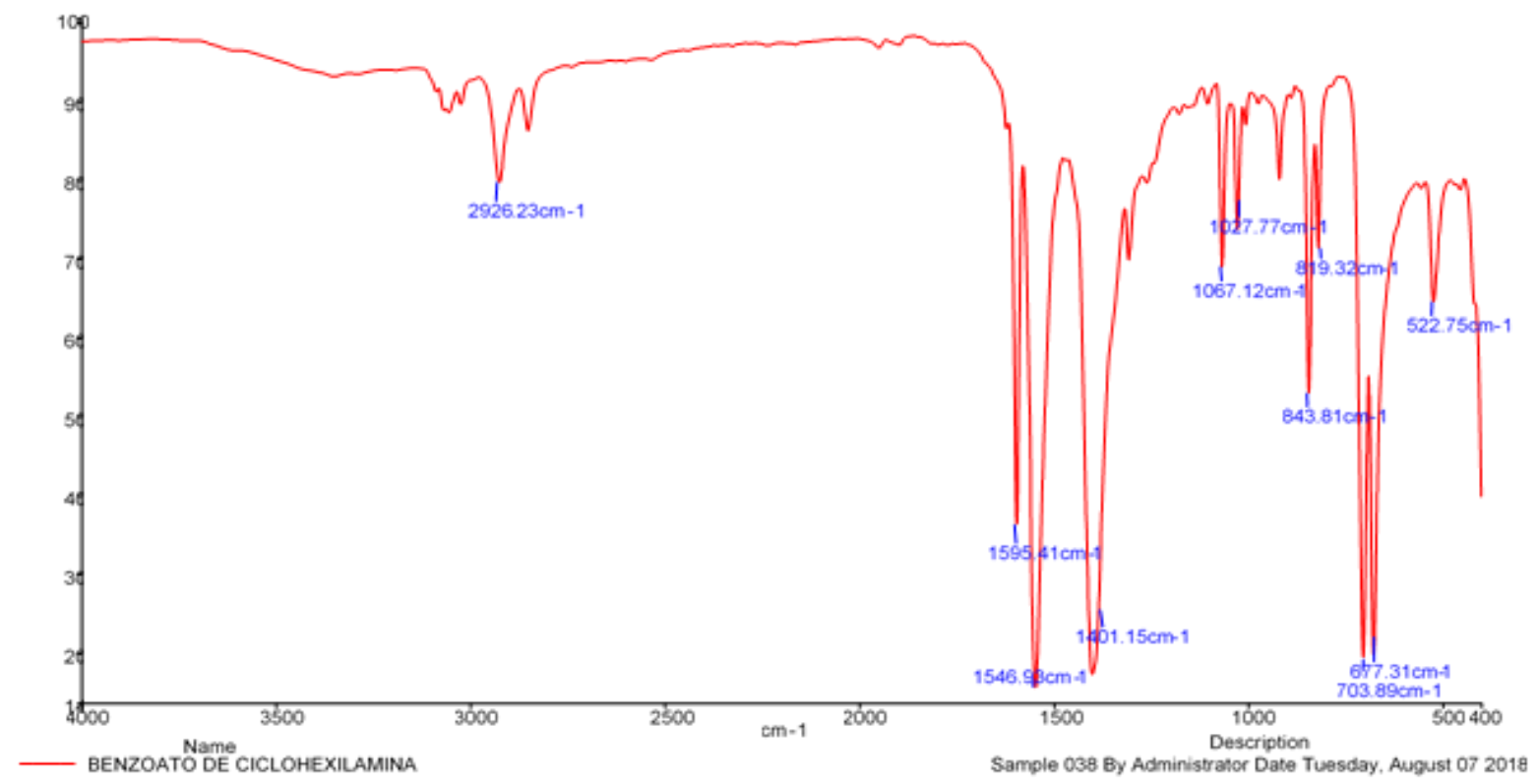

Figure 31. 0.25 CORPPRO FTIR spectrum. 
Table 5. Correlated functional groups of significant peaks in 0.25 CORPPRO FTIR spectrum.

\begin{tabular}{ccc}
\hline Wavenumber $\left(\mathbf{c m}^{-\mathbf{1}}\right)$ & Functional group & Transition \\
\hline$\approx 3300$ & Amine & $-\mathrm{N}-\mathrm{H}$ stretch \\
$3000-2850$ & Alkanes & $\mathrm{C}-\mathrm{H}$ stretch \\
$1640-1550$ & Primary and secondary amines & $\mathrm{N}-\mathrm{H}$ bend \\
1599 & Carboxylate & $\mathrm{COO}^{-}$asym stretch \\
$1390-1410$ & Carboxylate & $\mathrm{COO}^{-}$sym stretch \\
$1300-1450$ & Aromatic & $\mathrm{C}-\mathrm{C}$ stretch \\
\hline
\end{tabular}

The spectrum shown in Figure 3 has a peaks at around $2927 \mathrm{~cm}^{-1}$, this could be due to carboxylate $\mathrm{O}-\mathrm{H}$ stretching or alkane $\mathrm{C}-\mathrm{H}$ stretching. The peaks at $1595 \mathrm{~cm}^{-1}$ and 1547 are due to $\mathrm{COO}^{-}$asymmetric stretch or primary/secondary amine $\mathrm{N}-\mathrm{H}$ bending. The peak at $1401 \mathrm{~cm}^{-1}$ corresponds to carboxylate $\mathrm{COO}^{-}$symmetric stretching. The wavenumber, functional groups and transition are presented in Table 5.

Based on the absorption peaks present in the spectrum, it is likely CORPPRO contains an organic compound amine carboxylate aromatic type. This matches the description of CORPPRO in its MSDS which states that CORPPRO contains "amine carboxylate".

\section{Conclusions}

The following conclusions can be derived based on the results obtained:

1. The optimum concentration for VAPPRO 837C formulations to achieve the highest corrosion reduction efficiency is 0.25 CORPPRO according to the optimum drying time.

2. The optimum processing parameters to achieve a short processing time without sacrificing corrosion reduction efficiency for coating carbon steel samples are $10 \mathrm{~min}$ coating and $24 \mathrm{~h}$ drying, as seen in effect of varying coating time on corrosion reduction efficiency and effect of varying drying time on corrosion reduction efficiency.

3. The formulations were found to have stable viscosity over a 5 week period. The viscosities were also stable after freeze thawing for two cycles. This would suggest that there is no degradation of the VCI over the 5 week period and from freezing. But further testing is required to determine the amount of anti-freeze required to prevent freezing since the formulations with $1 \%$ antifreeze still froze at $-18^{\circ} \mathrm{C}$. This can be seen in Viscosity Stability Tests and Freeze-thaw Tests. 


\section{References}

1. E. McCafferty, Introduction to Corrosion Science, Springer, 2010, 5.

2. M.G. Fontana, Corros. Eng., McGraw-Hill, 1986, 1, 2.

3. E. Lyublinski, P. Lynch, I. Roytman and T. Yakubovskaya, Application Experience and New Approaches for Volatile Corrosion Inhibitors, Int. J. Corros. Scale Inhib., 2015, 4, no. 2, 176-192. doi: 10.17675/2305-6894-2015-4-2-110-115

4. N.N. Andreev and Y.I. Kuznetsov, Volatile Inhibitors of Metal Corrosion. I. Vaporization, Int. J. Corros. Scale Inhib., 2012, 1, no. 1, 16-25. doi: 10.17675/23056894-2012-1-1-016-025

5. J. Granath, Overview of Corrosion Protection with Volatile Corrosion Inhibitors, ECS Transactions, 2010, 25, no. 30, 15-21. doi: 10.1149/1.3321953

6. M. Prenosil, Volatile Corrosion Inhibitors, Cortec Corp., 2001, 14-17.

7. National Research Council, Research Opportunities in Corrosion Science and Engineering, DC, The National Academies Press, 2011. doi: 10.17226/13032

8. N.N. Andreev, O.A. Goncharova and S.S. Vesely, Volatile Inhibitors of Atmospheric Corrosion. IV. Evolution of Vapor-Phase Protection in the Light of Patent Literature, Int. J. Corros. Scale Inhib., 2013, 2, no. 3, 162-193. doi: 10.17675/2305-6894-2013-23-162-193

9. I.A. Gedvillo, S.V. Oleinik, I.S. Sivokon and N.N. Andreev, Laboratory Assessment of the Efficiency of Corrosion Inhibitors at Oilfield Pipelines of the West Siberia region V. Rotating cylinder and cage, Int. J. Corros. Scale Inhib., 2013, 2, no. 4, 287-303. doi: 10.17675/2305-6894-2013-2-4-287-303

10. D.A. Bayliss and D.H. Deacon, Treatment of the Air in Steelwork Corrosion Control, CRC Press, 2003, 174.

11. J.A. Quitmeyer, Amine Carboxylates: Additives in Metalworking Fluids, Soc. Tribol. Lubr. Eng., 1996, 52, 835.

12. L.H. Hihara, R.P.I. Adler and R.M. Latanision, Environmental Degradation of Advanced and Traditional Engineering Materials, CRC Press, 2013, 98.

13. ASTM G-1(2003), Standard practice for preparing, cleaning and evaluating corrosion test specimens, West Conshohocken, PA, 2003, www.astm.org.

14. Singapore Drinking Water Quality (July 2017 - June 2018), Singapore's National Water https://www.pub.gov.sg/Documents/Singapore_Drinking_Water_Quality.pdf

Quality.

15. J. Holden, A. Hansen, A. Furman, R. Kharshan and E. Austin, Vapor corrosion inhibitors in hydro-testing and long term storage applications, NACE International, Conference paper No. 10405, Corrosion conference and Expo 2010.

16. ASTM D2243-95(2008), Standard Test Method for Freeze-Thaw Resistance of WaterBorne Coatings, ASTM International, West Conshohocken, PA, 2008, www.astm.org. 
17. F.A. Ansari, C. Verma, Y.S. Siddiqui, E.E. Ebenso and M.A. Quraishi, Volatile Corrosion Inhibitors for Ferrous and Non-ferrous metals and Alloys: a review, Int. J. Corros. Scale Inhib., 2018, 7, no. 2, 126-150. doi: 10.17675/2305-6894-2018-7-2-2

18. B.E. Brycki, I.H. Kowalczyk, A. Szulc, O. Kaczerewska and M. Pakiet, Organic Corrosion Inhibitors, IntechOpen, 2017.

19. G. Camila, D. Galio and A. Galio, Corrosion Inhibitors - Principles, Mechanisms and Applications, IntechOpen, 2014.

20. L.M. Rymer, M. Sieber, S. Lautner and F. Faßbender, Operating Principle of Volatile Corrosion Inhibitors in the Jar Test, IOP Conf. Series: Materials Science and Engineering, 2019.

21. M. Sieber, S. Lautner and F. Faßbender, Evaluation of Volatile Corrosion Inhibitors in the Presence of Condensation Water by Electrochemical Methods, IOP Conf. Series: Materials Science and Engineering, 2019.

22. M.A. Quraishi and D. Jamal, Development and Testing of All Organic Volatile Corrosion Inhibitors, Corrosion, 2002, 58, no. 5, 387-391. 


\section{Annex 1}
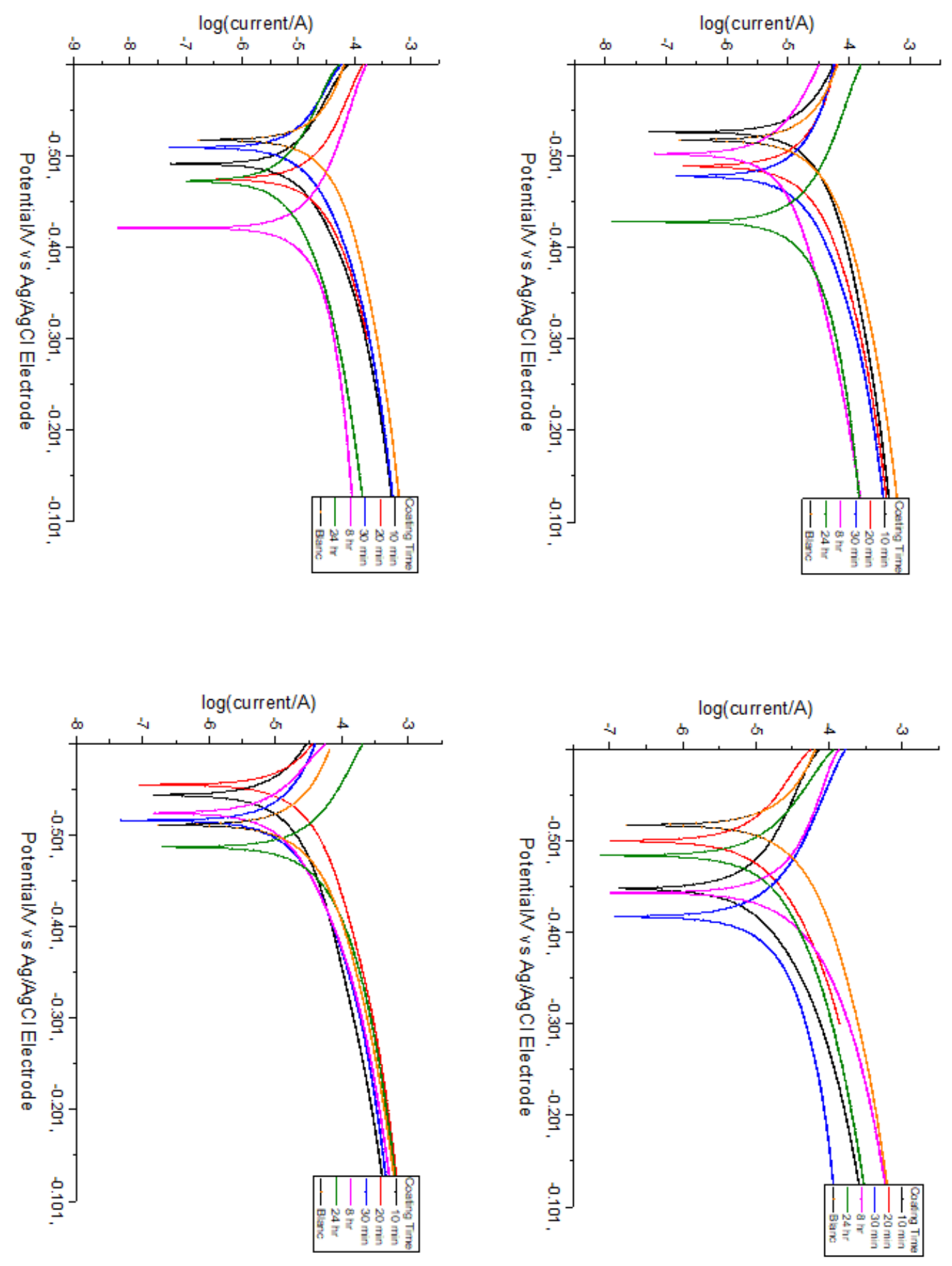

Figure 4. $1 \mathrm{~h}$ of drying. $0.25,0.5,0.75,1.0$ CORPPRO. 

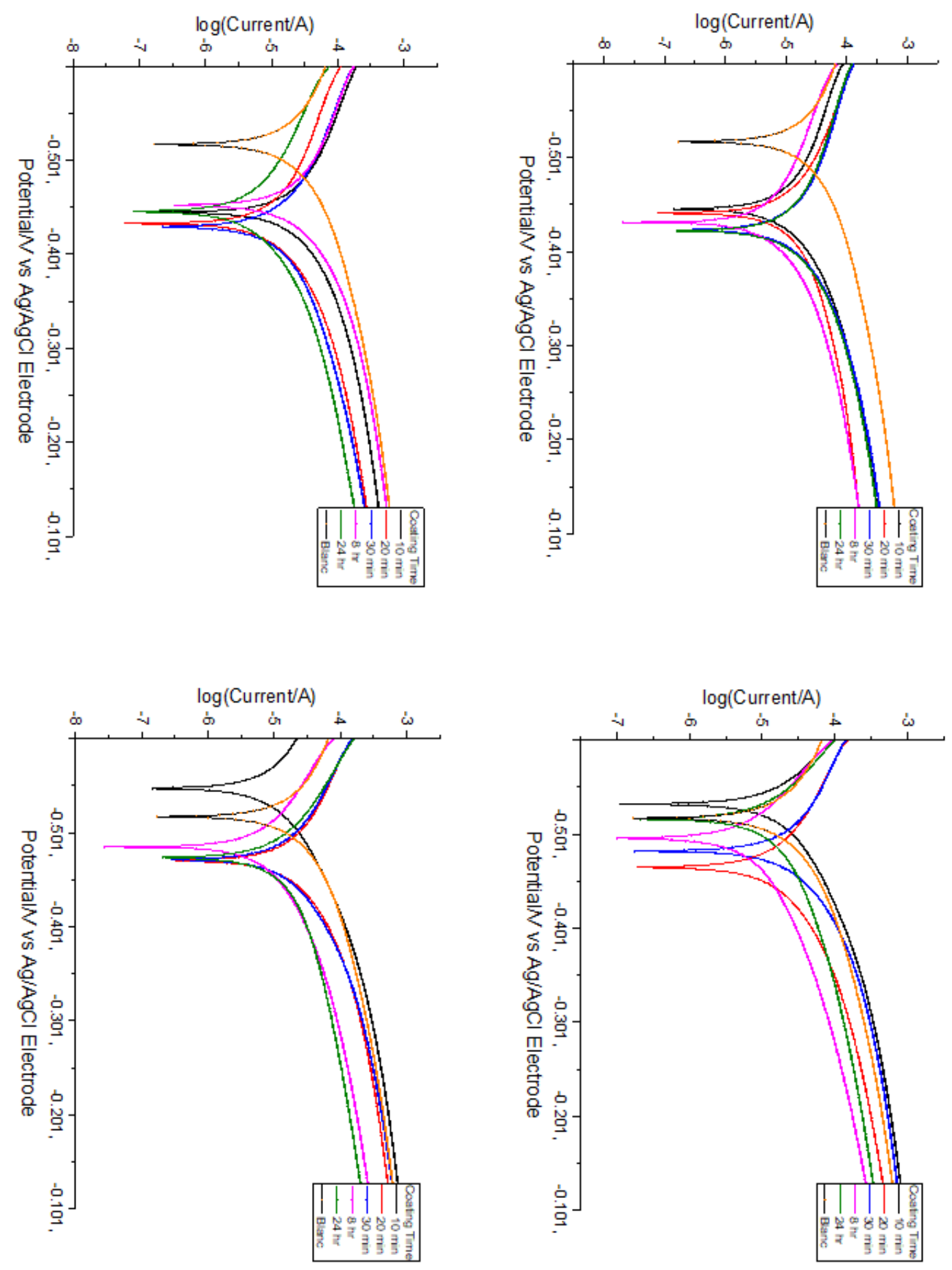

Figure 5. $2 \mathrm{~h}$ of drying. $0.25,0.5,0.75,1.0$ CORPPRO. 

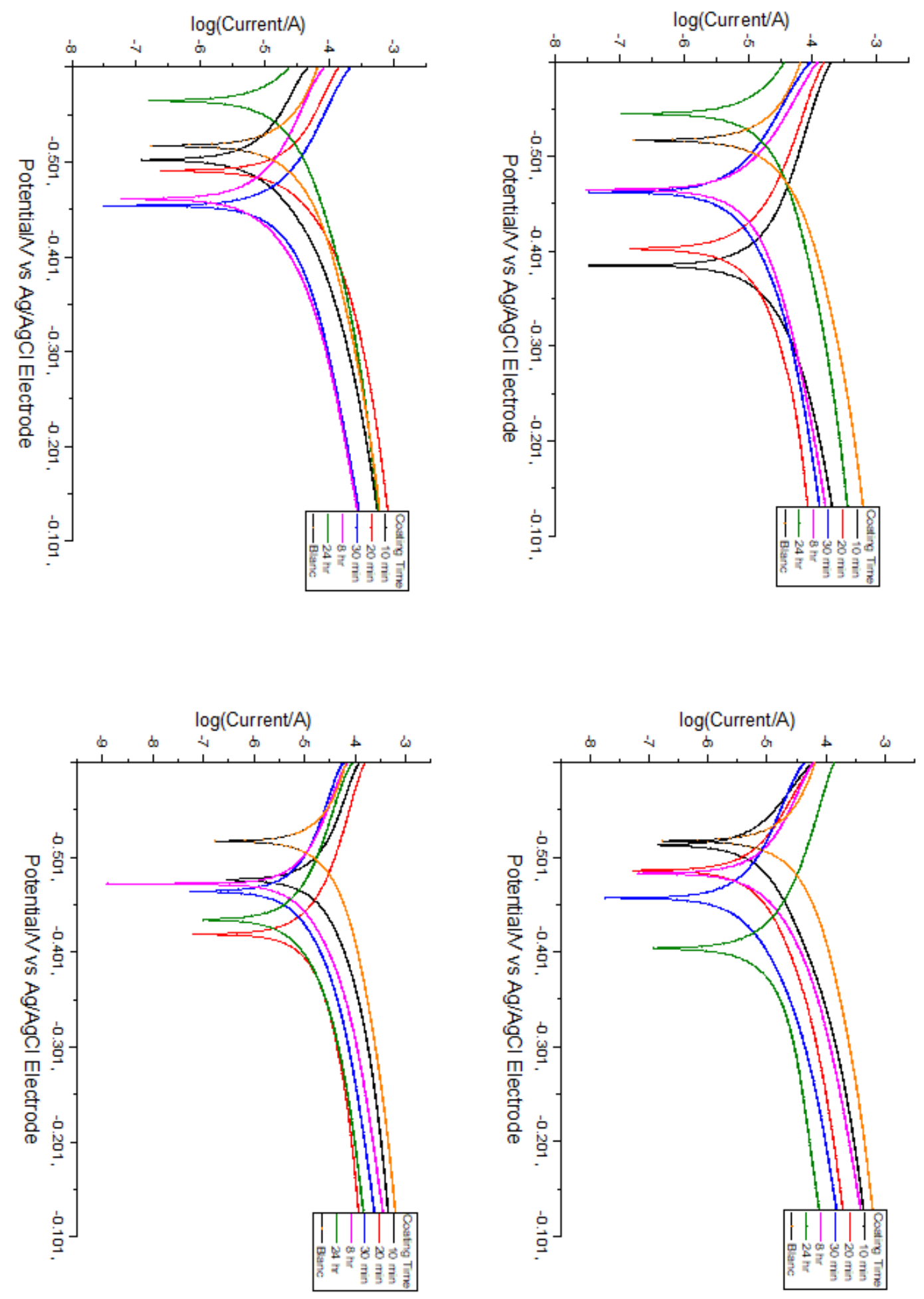

Figure 6. $5 \mathrm{~h}$ of drying. $0.25,0.5,0.75,1.0$ CORPPRO. 

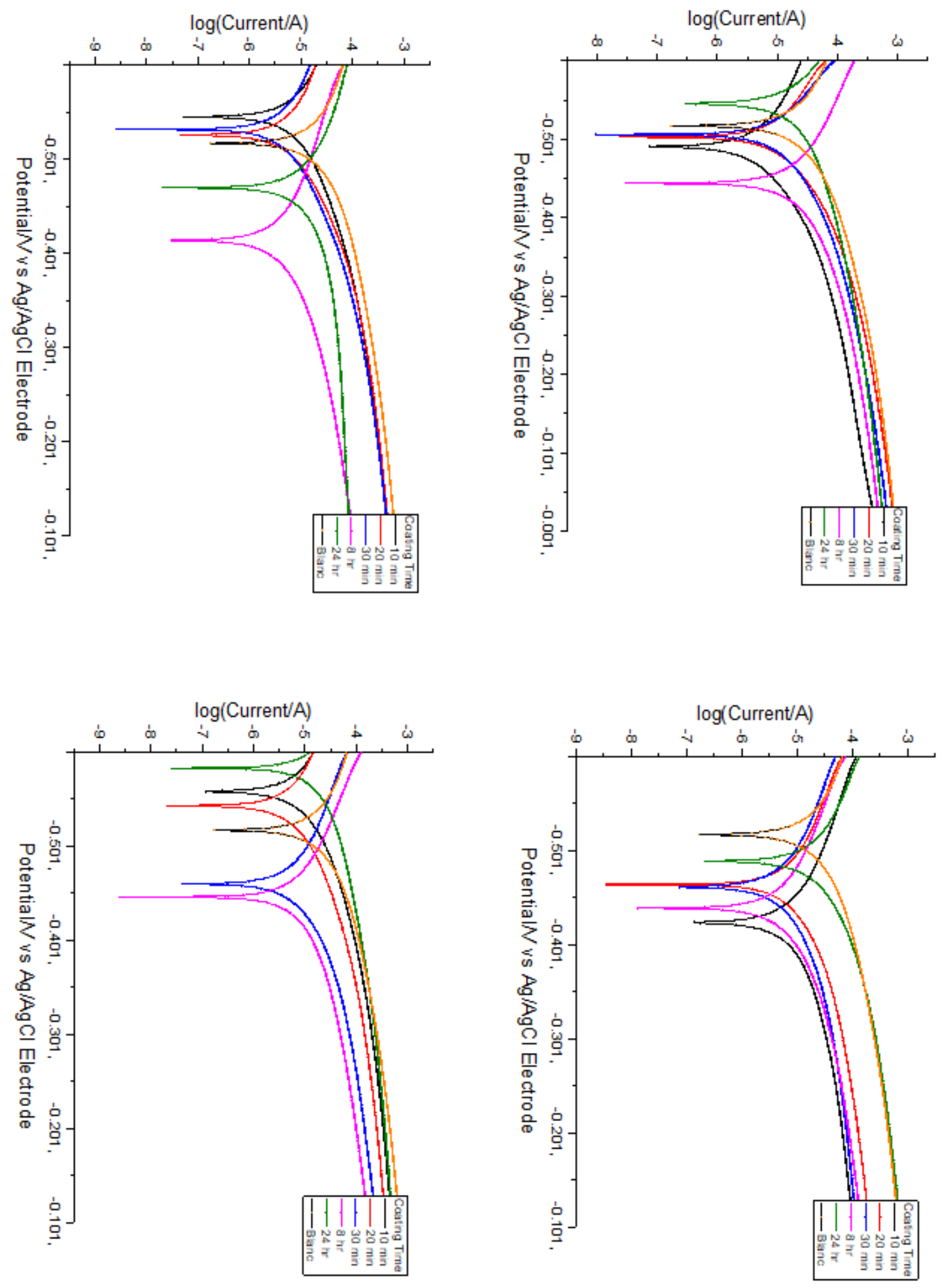

Figure 7. $24 \mathrm{~h}$ of drying. 0.25, 0.5, 0.75, 1.0 CORPPRO. 


\section{Annex 2}

Table 6. Results obtained from polarization curves for carbon steel with different concentrations of VAPPRO CORPPRO (Drying time $1 \mathrm{~h}$ ).

\begin{tabular}{|c|c|c|c|c|c|}
\hline $\begin{array}{c}\text { Concentration } \\
(\text { vol \%) }\end{array}$ & Coating time & $E_{\text {corr }}(\mathbf{V})$ & $\begin{array}{c}I_{\text {corr }} \\
\left(\mu \mathrm{A} \mathrm{cm}^{-2}\right)\end{array}$ & $\begin{array}{c}\text { Corrosion } \\
\text { Rate } \\
\text { (mm/year) }\end{array}$ & Efficiency (\%) \\
\hline \multirow{6}{*}{0.25} & Blank & -0.518 & 0.4576 & 0.643 & \\
\hline & $10 \mathrm{~min}$ & -0.527 & 0.2893 & 0.501 & 22.08 \\
\hline & $20 \mathrm{~min}$ & -0.49 & 0.2613 & 0.476 & 25.97 \\
\hline & $30 \mathrm{~min}$ & -0.479 & 0.2066 & 0.377 & 41.37 \\
\hline & $8 \mathrm{~h}$ & -0.503 & 0.08183 & 0.12 & 81.34 \\
\hline & $24 \mathrm{~h}$ & -0.429 & 0.2065 & 0.3815 & 40.67 \\
\hline \multirow{5}{*}{0.50} & $10 \mathrm{~min}$ & -0.545 & 0.1853 & 0.345 & 46.35 \\
\hline & $20 \mathrm{~min}$ & -0.556 & 0.3094 & 0.571 & 11.20 \\
\hline & $30 \mathrm{~min}$ & -0.517 & 0.1971 & 0.364 & 43.39 \\
\hline & $8 \mathrm{~h}$ & -0.525 & 0.03852 & 0.056 & 91.29 \\
\hline & $24 \mathrm{~h}$ & -0.488 & 0.4198 & 0.463 & 27.99 \\
\hline \multirow{5}{*}{0.75} & $10 \mathrm{~min}$ & -0.449 & 0.1094 & 0.202 & 68.58 \\
\hline & $20 \mathrm{~min}$ & -0.501 & 0.1115 & 0.426 & 33.75 \\
\hline & $30 \mathrm{~min}$ & -0.418 & 0.1831 & 0.338 & 47.43 \\
\hline & $8 \mathrm{~h}$ & -0.443 & 0.3177 & 0.469 & 27.06 \\
\hline & $24 \mathrm{~h}$ & -0.485 & 0.1445 & 0.266 & 58.63 \\
\hline \multirow{5}{*}{1.0} & $10 \mathrm{~min}$ & -0.492 & 0.1007 & 0.186 & 71.07 \\
\hline & $20 \mathrm{~min}$ & -0.476 & 0.2449 & 0.453 & 29.55 \\
\hline & $30 \mathrm{~min}$ & -0.51 & 0.0347 & 0.064 & 90.05 \\
\hline & $8 \mathrm{~h}$ & -0.422 & 0.1845 & 0.34 & 47.12 \\
\hline & $24 \mathrm{~h}$ & -0.473 & 0.06921 & 0.102 & 84.14 \\
\hline
\end{tabular}


Table 7. Results obtained from polarization curves for cabon steel with different concentrations of VAPPRO CORPPRO (Drying time $2 \mathrm{~h}$ ).

\begin{tabular}{|c|c|c|c|c|c|}
\hline $\begin{array}{c}\text { Concentration } \\
(\text { vol } \%)\end{array}$ & Coating time & $E_{\text {corr }}(\mathbf{V})$ & $\begin{array}{c}I_{\text {corr }} \\
\left(\mu \mathrm{A} \mathrm{cm}^{-2}\right)\end{array}$ & $\begin{array}{c}\text { Corrosion } \\
\text { Rate } \\
\text { (mm/year) }\end{array}$ & Efficiency (\%) \\
\hline \multirow{6}{*}{0.25} & Blank & -0.518 & 0.4576 & 0.643 & \\
\hline & $10 \mathrm{~min}$ & -0.446 & 0.1655 & 0.305 & 54.25 \\
\hline & $20 \mathrm{~min}$ & -0.442 & 0.1755 & 0.324 & 51.20 \\
\hline & $30 \mathrm{~min}$ & -0.424 & 0.2111 & 0.39 & 40.61 \\
\hline & $8 \mathrm{~h}$ & -0.432 & 0.08577 & 0.126 & 82.99 \\
\hline & $24 \mathrm{~h}$ & -0.423 & 0.2035 & 0.3 & 55.06 \\
\hline \multirow{5}{*}{0.50} & $10 \min$ & -0.533 & 0.08052 & 0.148 & 79.45 \\
\hline & $20 \mathrm{~min}$ & -0.466 & 0.2377 & 0.439 & 32.74 \\
\hline & $30 \mathrm{~min}$ & -0.483 & 0.3701 & 0.583 & 9.63 \\
\hline & $8 \mathrm{~h}$ & -0.497 & 0.08001 & 0.118 & 84.27 \\
\hline & $24 \mathrm{~h}$ & -0.517 & 0.05817 & 0.107 & 86.04 \\
\hline \multirow{5}{*}{0.75} & $10 \mathrm{~min}$ & -0.548 & 0.1441 & 0.212 & 69.18 \\
\hline & $20 \mathrm{~min}$ & -0.471 & 0.2774 & 0.512 & 21.03 \\
\hline & $30 \mathrm{~min}$ & -0.473 & 0.2236 & 0.413 & 36.92 \\
\hline & $8 \mathrm{~h}$ & -0.485 & 0.09218 & 0.136 & 81.38 \\
\hline & $24 \mathrm{~h}$ & -0.475 & 0.1726 & 0.319 & 52.01 \\
\hline \multirow{5}{*}{1.0} & $10 \mathrm{~min}$ & -0.446 & 0.3358 & 0.618 & 4.01 \\
\hline & $20 \min$ & -0.434 & 0.1722 & 0.318 & $52.17 \%$ \\
\hline & $30 \mathrm{~min}$ & -0.43 & 0.2025 & 0.374 & $43.18 \%$ \\
\hline & $8 \mathrm{~h}$ & -0.453 & 0.3664 & 0.616 & $4.33 \%$ \\
\hline & $24 \mathrm{~h}$ & -0.477 & 0.07589 & 0.112 & $85.23 \%$ \\
\hline
\end{tabular}


Table 8. Results obtained from polarization curves for carbon steel with different concentrations of VAPPRO CORPPRO (Drying time $5 \mathrm{~h}$ ).

\begin{tabular}{|c|c|c|c|c|c|}
\hline $\begin{array}{c}\text { Concentration } \\
(\text { vol } \%)\end{array}$ & Coating time & $E_{\text {corr }}(\mathbf{V})$ & $\begin{array}{c}I_{\text {corr }} \\
\left(\mu \mathrm{A} \mathrm{cm}^{-2}\right)\end{array}$ & $\begin{array}{c}\text { Corrosion } \\
\text { Rate } \\
\text { (mm/year) }\end{array}$ & Efficiency (\%) \\
\hline \multirow{6}{*}{0.25} & Blanc & -0.518 & 0.4576 & 0.643 & \\
\hline & $10 \mathrm{~min}$ & -0.386 & 0.1999 & 0.37 & 42.46 \\
\hline & $20 \mathrm{~min}$ & -0.404 & 0.1385 & 0.255 & 60.34 \\
\hline & $30 \mathrm{~min}$ & -0.463 & 0.07362 & 0.136 & 78.85 \\
\hline & $8 \mathrm{~h}$ & -0.466 & 0.1022 & 0.15 & 76.67 \\
\hline & $24 \mathrm{~h}$ & -0.546 & 0.2198 & 0.324 & 49.61 \\
\hline \multirow{5}{*}{0.50} & $10 \mathrm{~min}$ & -0.514 & 0.1928 & 0.356 & 44.63 \\
\hline & $20 \mathrm{~min}$ & -0.487 & 0.07031 & 0.123 & 80.87 \\
\hline & $30 \mathrm{~min}$ & -0.458 & 0.04859 & 0.089 & 86.16 \\
\hline & $8 \mathrm{~h}$ & -0.484 & 0.1034 & 0.152 & 76.36 \\
\hline & $24 \mathrm{~h}$ & -0.405 & 0.1473 & 0.286 & 55.52 \\
\hline \multirow{5}{*}{0.75} & $10 \mathrm{~min}$ & -0.503 & 0.1051 & 0.194 & 69.83 \\
\hline & $20 \mathrm{~min}$ & -0.492 & 0.3276 & 0.5651 & 12.12 \\
\hline & $30 \mathrm{~min}$ & -0.455 & 0.2146 & 0.396 & 38.41 \\
\hline & $8 \mathrm{~h}$ & -0.462 & 0.1088 & 0.16 & 75.12 \\
\hline & $24 \mathrm{~h}$ & -0.566 & 0.2143 & 0.316 & 50.86 \\
\hline \multirow{5}{*}{1.0} & $10 \mathrm{~min}$ & -0.477 & 0.2384 & 0.44 & 31.57 \\
\hline & $20 \min$ & -0.42 & 0.1613 & 0.298 & 53.65 \\
\hline & $30 \mathrm{~min}$ & -0.465 & 0.0885 & 0.164 & 74.49 \\
\hline & $8 \mathrm{~h}$ & -0.473 & 0.0971 & 0.143 & 77.76 \\
\hline & $24 \mathrm{~h}$ & -0.435 & 0.08684 & 0.128 & 80.09 \\
\hline
\end{tabular}


Table 9. Results obtained from polarization curves for carbon steel with different concentrations of VAPPRO CORPPRO (Drying time $24 \mathrm{~h}$ ).

\begin{tabular}{|c|c|c|c|c|c|}
\hline $\begin{array}{c}\text { Concentration } \\
(\text { vol } \%)\end{array}$ & Coating time & $E_{\text {corr }}(\mathbf{V})$ & $\begin{array}{c}I_{\text {corr }} \\
\left(\mu \mathrm{A} \mathrm{cm}^{-2}\right)\end{array}$ & $\begin{array}{c}\text { Corrosion } \\
\text { Rate } \\
\text { (mm/year) }\end{array}$ & Efficiency (\%) \\
\hline \multirow{6}{*}{0.25} & Blanc & -0.518 & 0.4576 & 0.643 & \\
\hline & $10 \mathrm{~min}$ & -0.504 & 0.06517 & 0.096 & 85.07 \\
\hline & $20 \mathrm{~min}$ & -0.507 & 0.1209 & 0.178 & 72.32 \\
\hline & $30 \mathrm{~min}$ & -0.445 & 0.1174 & 0.173 & 73.09 \\
\hline & $8 \mathrm{~h}$ & -0.547 & 0.2731 & 0.504 & 21.62 \\
\hline & $24 \mathrm{~h}$ & -0.492 & 0.2689 & 0.397 & 38.26 \\
\hline \multirow{5}{*}{0.5} & $10 \mathrm{~min}$ & -0.425 & 0.1191 & 0.175 & 72.78 \\
\hline & $20 \mathrm{~min}$ & -0.465 & 0.1088 & 0.16 & 75.12 \\
\hline & $30 \mathrm{~min}$ & -0.462 & 0.08547 & 0.126 & 80.40 \\
\hline & $8 \mathrm{~h}$ & -0.44 & 0.0777 & 0.114 & 82.27 \\
\hline & $24 \mathrm{~h}$ & -0.49 & 0.3139 & 0.463 & 27.99 \\
\hline \multirow{5}{*}{0.75} & $10 \mathrm{~min}$ & -0.559 & 0.1274 & 0.188 & 70.76 \\
\hline & $20 \mathrm{~min}$ & -0.544 & 0.09266 & 0.136 & 78.85 \\
\hline & $30 \mathrm{~min}$ & -0.461 & 0.09375 & 0.138 & 78.54 \\
\hline & $8 \mathrm{~h}$ & -0.447 & 0.1013 & 0.149 & 76.83 \\
\hline & $24 \mathrm{~h}$ & -0.584 & 0.2314 & 0.341 & 46.97 \\
\hline \multirow{5}{*}{1.0} & $10 \mathrm{~min}$ & -0.546 & 0.1061 & 0.156 & 75.74 \\
\hline & $20 \min$ & -0.527 & 0.0883 & 0.13 & 79.78 \\
\hline & $30 \mathrm{~min}$ & -0.533 & 0.06786 & 0.1 & 84.45 \\
\hline & $8 \mathrm{~h}$ & -0.415 & 0.05728 & 0.105 & 83.67 \\
\hline & $24 \mathrm{~h}$ & -0.471 & 0.2035 & 0.3 & 53.34 \\
\hline
\end{tabular}

